\title{
Contribution of Diagnosis Examinations in Pulmonary Embolism
}

\author{
Machihude Pio1, Doguessaga Borgiata Atta ${ }^{2}$, Yaovi Mignazonzon Afassinou ${ }^{3}$, Soulemane Pessinaba ${ }^{4}$, \\ Hamza Doles Sama ${ }^{3}$, Tchaa Tchérou ${ }^{1}$, Ablavi Ena Todo-Alipui ${ }^{3}$, Wiyaou Dieudonnné Kaziga4, \\ Abalo Mario Bakai', Soodougoua Baragou ${ }^{3}$, Findibé Damorou ${ }^{4}$ \\ ${ }^{1}$ Cardiology Department, Kara Unviversity Hospital, Kara, Togo \\ ${ }^{2}$ Cardiology Department, Sokode Hospital, Togo \\ ${ }^{3}$ Cardiology Department, Sylvanus Olympio University Hospital, Lomé, Togo \\ ${ }^{4}$ Cardiology Department, Campus University Hospital, Lomé, Togo \\ Email: pimae2002@yahoo.fr
}

How to cite this paper: Pio, M., Atta, D.B. Afassinou, Y.M., Pessinaba, S., Sama, H.D., Tchérou, T., Todo-Alipui, A.E., Kaziga, W.D., Bakai, A.M., Baragou, S. and Damorou, F. (2021) Contribution of Diagnosis Examinations in Pulmonary Embolism. World Journal of Cardiovascular Diseases, 11, 564-571. https://doi.org/10.4236/wjcd.2021.1112053

Received: October 11, 2021

Accepted: December 10, 2021

Published: December 13, 2021

Copyright $\odot 2021$ by author(s) and Scientific Research Publishing Inc. This work is licensed under the Creative Commons Attribution International License (CC BY 4.0).

http://creativecommons.org/licenses/by/4.0/ (c) (i) Open Access

\begin{abstract}
Background: We aimed to determine the specificities of pulmonary embolism (PE) investigations and their statistical link according to PE's degrees of severity. Patients and Methods: It was a cross-sectional study on patientrecords admitted in Cardiology Department for PE, from June $1^{\text {st }} 2014$ to April $30^{\text {th }}$ 2019. We studied electrocardiogram (ECG), Chest X-ray, Echocardiographic, D-dimers, CT pulmonary angiographic (CTPA) data. PE diagnosis was retained at the CTPA. PE was classified according to its severity (low, intermediate, and severe). Patients were arbitrarily categorized in 4 groups (G1 - G4) according to D-dimer level. Results: We retained 110 patientrecords of patients mean aged $56 \pm 15$ years, with female predominance (Sex-ratio $F / M=1.82$ ). Patients with main pulmonary artery's (MPA) embolism had D-dimer value $>5000 \mathrm{ng} / \mathrm{mL}$. The more proximal embolism was located, the higher D-dimer level was, but no significant association was found between D-dimer level and PE's severity. CTPA showed bilateral location of embolism in $52 \%$ of cases. Severe PE (SPE) was significantly associated to proximal location (main and segmental branches of PA), and repolarization disorders. $S_{1} Q_{3}$ aspect was associated to intermediate mortality risk PE. On chest $\mathrm{X}$-ray, cardiomegaly and the left middle arch convexity were associated to SPE. PAH was significantly associated to SPE. Conclusion: PE, serious disease has the diagnostic challenge according to its clinical presentations. Several findings of PE investigations should be useful for SPE assessment in our areas, especially since CTPA is not often accessible, even in urban cities.
\end{abstract}

\section{Keywords}

Pulmonary Embolism, D-Dimer, Severity, Diagnosis, Togo 


\section{Introduction}

Pulmonary embolism (PE) is a sudden partial or total obstruction of the pulmonary artery (PA) or one of its branches by a foreign body, most often a blood clot or thrombus [1]. It is ubiquitous, serious and frequent. In Europe, the prevalence of $\mathrm{PE}$ is 17 to $42.6 \%$ of hospitalized patients and 8 to $52 \%$ of post-mortem examinations [2] [3].

The prevalence of pulmonary embolism (PE) is increasing in sub-Saharan Africa ranging from $1.4 \%$ to $7 \%$ [4] [5] [6] [7] [8]. PE, a life-threatening condition, is characterized by variable clinical pictures. Investigations for diagnosis of PE are numerous. Electrocardiogram (ECG), chest X-ray, cardiac Doppler ultrasound and D-dimer testing are orientation exams while lung scintigraphy and chest CT angiography are certainty exams [9]. Lung scintigraphy is very scarce in Africa and CT angiography is not always available in most hospitals outside of the capital cities in sub-Saharan Africa. However, PE is an emergency and the clinical picture can rapidly evolve from minor form to severe form [10]. The physician in this context must, from the clinic and the referral examinations, initiate and adapt the therapeutic protocol early, before confirming the diagnosis if possible by thoracic CT angiography. The aims of our study were to determine the particularities of these orientation exams and correlate them with the different degrees of severity of PE.

\section{Patients and Methods}

This was a cross-sectional study on files of patients hospitalized for PE in the cardiology department of the Sylvanus Olympio University Hospital in Lomé from $1^{\text {st }}$ June 2014 to 30 April 2019 (5 years).

Were included in the study, files of patients in whom the diagnosis of PE was confirmed by CT angiography and including data from ECG, chest X-ray, cardiac doppler ultrasound and D-dimers. Incomplete charts and patients who did not perform CT angiography were excluded from this study.

We reported the interpretations made by cardiologists and radiologists of these examinations. We studied:

- On the ECG: repolarization disorders such as anterior sub-epicardial ischemia (V1 to V5).

- On echocardiography: dilation of the right ventricle (RV) defined by RV/LV ratio $>1$, dilation of the right atrium (OD) if the area was greater than 18 $\mathrm{cm}^{2}$. The RV dysfunction threshold was set at a TAPSE value of less than 16 $\mathrm{mm}$, pulmonary arterial hypertension $(\mathrm{PAH})$ was defined as systolic pulmonary arterial pressure (PAPS) greater than $35 \mathrm{mmHg}$.

The diagnosis of PE was confirmed by CT angiography.

Patient charts were classified according to the severity of PE (low, intermediate or severe risk). The patients were classified into classes according to D-dimers level: group 1 (G1), D-dimers < $1000 \mathrm{ng} / \mathrm{mL}$, group 2 (G2) D-dimers 1001 - 3000 $\mathrm{ng} / \mathrm{mL}$, group 3 (G3), D-dimers 3001 - $5000 \mathrm{ng} / \mathrm{mL}$, and group 4 (G4), D-dimers 
were $>5000 \mathrm{ng} / \mathrm{mL}$.

We did a binary logistic regression. Considering separately each level of D dimers with the severity of PE. We also analyzed each level of severity of PE with thrombus location, electrocardiographic abnormalities, radiographic abnormalities, and echocardiographic data. The threshold of statistical significance was $\mathrm{p}<0.05$.

\section{Results}

\section{Epidemiological characteristics}

One hundred ten cases were included. The mean age of the patients was $56 \pm$ 15 years. Sex ratio women/men was 1.82 . Women were more affected by PE with a high risk of mortality ( $60.5 \%$ of severe PE versus $39.5 \%$ for men). PE was severe in $34.6 \%$ of cases and at intermediate risk of death in $42.7 \%$ of patients.

Levels of D-dimer levels depending on the location of the thrombus and the severity of the pulmonary embolism

In $34 \%$ of patients the D-dimer level was between 1000 and $3000 \mathrm{ng} / \mathrm{mL}$ and in $14 \%$ of the patients the $\mathrm{D}$-dimer level was less than $1000 \mathrm{ng} / \mathrm{mL}$. All patients with a thrombus in the pulmonary artery trunk had a D-dimer level greater than $5000 \mathrm{ng} / \mathrm{mL}$. We found $21 \%$ of segmental EPs which also had a D-dimer level greater than $5000 \mathrm{ng} / \mathrm{mL}$ (Figure 1). In patients who had a D-dimer level between $3001 \mathrm{ng} / \mathrm{mL}$ and $5000 \mathrm{ng} / \mathrm{mL}$, thrombi were found more in the main branches of PA (29\%) and in those who had a lower D-dimer level at 1000 $\mathrm{ng} / \mathrm{mL}$ and between $1000 \mathrm{ng} / \mathrm{mL}$ and $3000 \mathrm{ng} / \mathrm{mL}$, the thrombus was found more in the segmental branches of the PA in $26 \%$ and $36 \%$ of cases, respectively. Therefore, the more proximal the localization, the higher the level of D-dimers. But there was no significant association between the level of elevation of D-dimers and the severity of PE (Table 1).

Location of the thrombus and severity of pulmonary embolism

$\mathrm{PE}$ was bilateral in $52 \%$ of cases. The branches of the pulmonary artery most

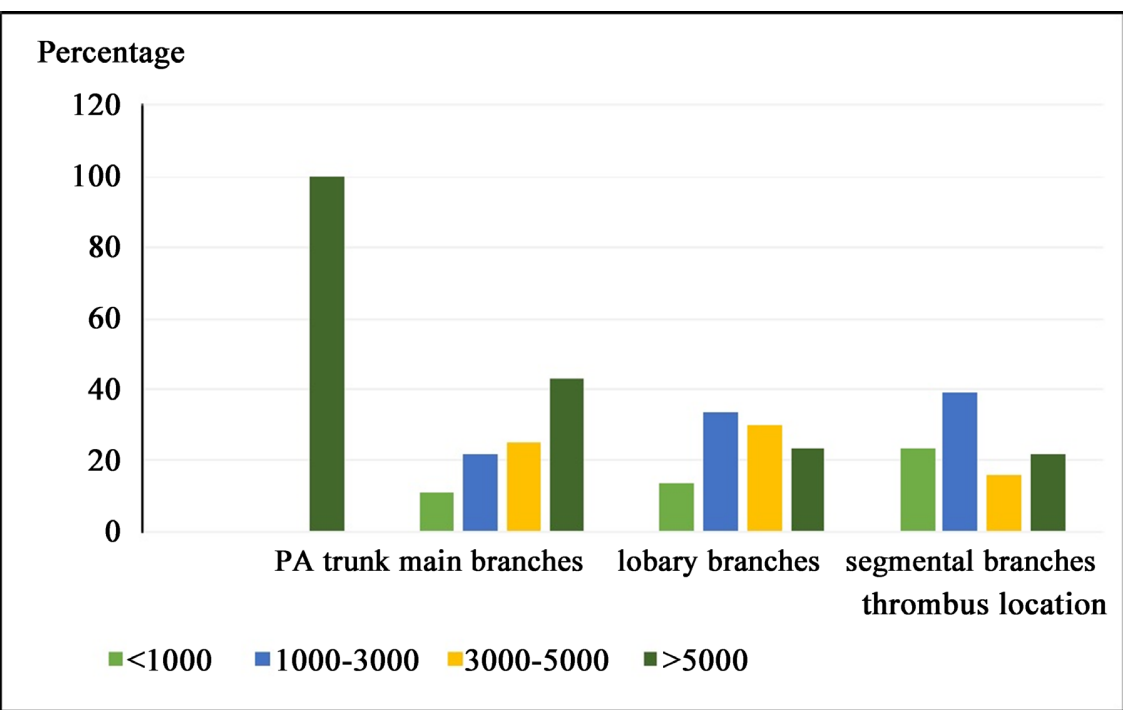

Figure 1. Location of the thrombus in pulmonary artery. 
affected were the segmental branches in $51 \%$ of cases followed by the main branches in $46 \%$ of cases. The trunk was affected in $5.4 \%$ of cases. Severe PE was significantly associated with localization of the thrombus in the trunk or lobar branches (Table 2).

\section{ECG abnormalities and severity of pulmonary embolism}

The ECG was normal in 11 patients (10\%). Sinus tachycardia was found in $72.7 \%$ of cases. An S1Q3 aspect was found in 55\%. Among the electrocardiographic abnormalities, anterior repolarization disorder was significantly associated with severe PE and the S1Q3 aspect was significantly present in PE at intermediate risk of mortality (Table 2).

\section{Chest radiographic aspects}

The chest $\mathrm{x}$-ray was normal in $7 \%$ of cases. Convexity of the left middle arch was the most common sign in $93 \%$ of cases, followed by cardiomegaly in $79 \%$ of cases. Cardiomegaly and convexity of the left middle arch were significantly found in severe PE (Table 2).

\section{Echocardiographic abnormalities and severity of pulmonary embolism}

Echocardiography was normal in $31.8 \%$ of cases. The abnormalies found were mainly right ventricle dilatation $(60.9 \%)$, right atrium dilatation (59\%), pulmonary arterial hypertension (64.5\%), paradoxical septum (48.1\%), right ventricular

Table 1. Association between pulmonary embolism severity and D-dimer level.

\begin{tabular}{|c|c|c|c|c|c|c|c|c|c|c|c|c|}
\hline & \multicolumn{3}{|c|}{$\begin{array}{c}\mathrm{G} 1(\mathrm{n}=15) \\
\mathrm{D}-\mathrm{d}<1000 \mathrm{ng} / \mathrm{mL}\end{array}$} & \multicolumn{3}{|c|}{$\begin{array}{c}\mathrm{G} 2(\mathrm{n}=37) \\
\mathrm{D}-\mathrm{d}[1000-3000 \mathrm{ng} / \mathrm{mL}]\end{array}$} & \multicolumn{3}{|c|}{$\begin{array}{c}\text { G3 }(n=26) \\
\text { D-d }[3001-5000 \mathrm{ng} / \mathrm{mL}]\end{array}$} & \multicolumn{3}{|c|}{$\begin{array}{c}\mathrm{G} 4(\mathrm{n}=32) \\
\mathrm{D}-\mathrm{d}>5000 \mathrm{ng} / \mathrm{mL}\end{array}$} \\
\hline & OR & IC 95\% & $\mathrm{p}$ & OR & IC 95\% & $\mathrm{p}$ & OR & IC 95\% & $\mathrm{p}$ & OR & IC $95 \%$ & $\mathrm{p}$ \\
\hline $\mathrm{PE}$ with high risk & 3.3 & $0.8-12.5$ & 0.08 & 0.3 & $0.1-1.2$ & 0.09 & 0.5 & $0.1-2.1$ & 0.37 & 2.1 & $0.7-6.7$ & 0.18 \\
\hline $\begin{array}{l}\text { PE with } \\
\text { intermediate risk }\end{array}$ & 0.3 & $0.1-1.4$ & 0.58 & 0.8 & $0.3-1.9$ & 0.67 & 1.5 & $0.6-3.7$ & 0.41 & 1.4 & $0.6-3.5$ & 0.41 \\
\hline PE with low risk & 1.4 & $0.4-4.9$ & 0.13 & 0.8 & $0.4-1.9$ & 0.66 & 0.6 & $0.2-1.5$ & 0.27 & 1.6 & $0.7-4.0$ & 0.26 \\
\hline
\end{tabular}

G1: Group 1; G2: Group 2; G3: Group 3; G4: Group 4; D-d: D-dimer; PE: pulmonary embolism.

Table 2. Association of paraclinical signs and severity of pulmonary embolism.

\begin{tabular}{|c|c|c|c|c|c|c|c|c|c|}
\hline & \multicolumn{3}{|c|}{ EP sévère $(n=24)$} & \multicolumn{3}{|c|}{ EP intermédiaire $(n=34)$} & \multicolumn{3}{|c|}{ EP faible $(n=52)$} \\
\hline & OR & IC 95\% & $\mathrm{p}$ & OR & IC 95\% & $\mathrm{p}$ & OR & IC 95\% & $\mathrm{p}$ \\
\hline \multicolumn{10}{|l|}{ Thrombus location } \\
\hline Trunk & 20.3 & $2.6-157.9$ & 0.004 & 0.4 & $0.1-2.9$ & 0.96 & 0.4 & $0.1-2.4$ & 0.28 \\
\hline Main branches & 2.1 & $0.7-5.9$ & 0.18 & 1.5 & $0.5-3.9$ & 0.40 & 0.4 & $0.1-1.1$ & 0.06 \\
\hline Lobary branches & 2.9 & $1.0-8.5$ & 0.04 & 0.3 & $0.1-0.9$ & 0.04 & 1.1 & $0.4-2.7$ & 0.80 \\
\hline Segmental branches & 1.5 & $0.5-4.3$ & 0.45 & 1.0 & $0.3-2.6$ & 0.99 & 0.8 & $0.3-1.8$ & 0.52 \\
\hline \multicolumn{10}{|c|}{ Electrocardiographic abnormalities } \\
\hline Repolarization abnormalities & 3.4 & $1.1-10.4$ & 0.03 & 1.5 & $0.5-4.1$ & 0.41 & 0.4 & $0.1-0.9$ & 0.04 \\
\hline Right QRS axis & 1.7 & $0.2-12.3$ & 0.61 & 1.4 & $0.2-7.6$ & 0.72 & 0.5 & $0.1-3.1$ & 0.45 \\
\hline
\end{tabular}


dysfunction with TAPSE $\leq 15 \mathrm{~mm}$ (46.3\%). Pulmonary arterial hypertension (PAH) was the only abnormality significantly associated with severe PE (Table 2).

\section{Discussion}

This study focused on the peculiarities of D-dimers, ECG, chest X-ray and echocardiography in PE at Sylvanus Olympio University hospital in Lomé.

Female predominance was founded in our study. This female predominance was also observed in the severity of PE. We believe that the mechanical and especially hormonal characteristics of the specific etiological factors of PE in women are the main reasons. Indeed, among the causes of venous thromboembolic disease (VTD), female sex has particularities: sedentary lifestyle and obesity which most affect women in our society [11] [12], the exclusive part of pregnancy, peripartum, peripartum cardiomyopathy, use of estrogen-progestogens, exclusivity of cervical, ovarian, uterine, uterine myomas and ovarian cysts in women [4] [8] [13].

Average age of the patients was $56.74 \pm 15.53$ years. In general, all authors agree on a significant increase in the incidence of VTD after 40 years [14] [15] [16].

In our series, the branches of the PA most affected were segmental branches in $51 \%$ of the cases, followed by main branches in $46 \%$. Ngamami et al. in Congo also had founded a predominance of segmental branches in $62.5 \%$ of cases [17]. We found $5.4 \%$ of patients with truncal PE like Houenassi et al. in Benin, who had founded 5\% [14]. This is likely an underestimation as the patient with truncal PE is at risk to not reach hospital, or to die in hospital before diagnostic confirmation. Autopsies are exceptional in our hospitals in sub-Saharan Africa.

We have arbitrarily distributed the D-dimers between certain random values in order to better understand a link between the level of D-dimers and the severity of PE. Ghanima [18] found a significant association between the level of $\mathrm{D}$-dimer and the most proximal level of PE as in our study. Contrary to our results, he also found a significant association between the level of elevation of $\mathrm{D}$-dimers and the severity of $\mathrm{PE}$ with potential interest as a prognostic indicator of severity of PE [18].

There was no association between D-dimer level and severity of PE in our study. D-dimers were therefore not an element that could allow us to assess the severity of $\mathrm{PE}$ in our context. But we observed that the truncal PE had D-dimers greater than $5000 \mathrm{ng} / \mathrm{mL}$. So D-dimers greater than $5000 \mathrm{ng} / \mathrm{mL}$ predict a proximal location of a thrombus and therefore potentially a progressive PE with severity.

Anterior repolarization anomalies were significantly more found in severe PE. The electrocardiographic signs found are those already reported in the literature with similar proportions [13] [17] [19].

A chest X-ray is not a key diagnostic exam for PE, and its normality does not preclude a diagnosis of PE [20]. Especially since the evolution of PE towards 
gravity is unpredictable. Cardiomegaly and convexity of the left middle arch were the radiographic signs associated with severe PE. They are the radiologic translation of dilation of the right heart chambers and pulmonary arterial hypertension, often signs of severity [9] [21].

S1Q3 aspect was significantly associated with intermediate risk PE. Anterior abnormalities on ECG, radiological cardiomegaly and convexity of the left middle arch could constitute paraclinical signs of the severity of PE in our settings where CT angiography is rarely available, and where patients are often not insured, with very limited of finances. Before patients confirm the diagnosis of PE, these clinical signs could participate in the classification of the severity of PE in our context.

Echocardiography is an exam that classifies PE according to severity. It is indeed easy to perform and non-invasive. She usually shows indirect signs of PE and indicating hemodynamic impact. Lambert in France found right ventricular dilation in $48.7 \%$ of cases, pulmonary arterial hypertension (PAH) in $45.2 \%$ of cases and intracardiac thrombus in 2.2\% of cases [9]. In Togo, Pio in 2014 found $\mathrm{PAH}$ in 50\% and thrombus in 3.44\% [21]. There are indeed small variations depending on the studies in these results but in each series the order of the lesions was the same: right cavitary dilation first followed by PAH, paradoxical septum and right ventricular dysfunction. Finally, a normal echocardiogram is more in favor of a PE with a low risk of mortality.

In total, D-dimer level greater than $5000 \mathrm{ng} / \mathrm{mL}$ is suspect of a truncal PE and therefore potentially progressing to severity. The presence of anterior repolarization disorder on ECG, cardiomegaly, convexity of the left middle arch on chest $\mathrm{X}$-ray, presence of PAH on echocardiography is significantly associated with severe PE. The S1Q3 aspect is significantly associated with PE with intermediate risk of mortality. These signs should help clinicians to anticipate the management and monitoring of these patients even if they appear to have a less worrisome clinical picture of PE.

\section{Conclusion}

$\mathrm{PE}$ is a serious condition and its positive diagnosis is sometimes difficult due to the clinical polymorphism. There was no association between D-dimer level and severity of PE, but rather with the location of the thrombus. Severe PE was more truncal. S1Q3 aspect is significantly associated with PE with intermediate risk of mortality. ECG repolarization abnormalities, cardiomegaly and convexity of the left middle arch on the chest $\mathrm{x}$-ray were associated with severe PE. PAH was the sign most significantly associated with severe PE on echocardiography. These signs could be elements of assessing the severity of PE in our low income countries.

\section{Conflicts of Interest}

The authors declare no conflicts of interest regarding the publication of this paper. 


\section{References}

[1] Cohen, A. (1997) Embolie Pulmonaire. In: Cardiologie et pathologies cardiovasculaires, Estem, Paris, 775-816.

[2] Boukinda, F., Planchon, B. and Okondza, J. (1996) La thrombophlébite profonde des membres inférieurs: Une curiosité clinique en Afrique noire; Notre expérience à Brazzaville. Médecine d' Afrique Noire, 43, 63-65.

[3] Barrelier, M.T., Lezin, B., Landy, S. and Le Hello, C. (2001) Prévalence de la hrombose veineuse diagnostiquée par échographie-doppler des membres inférieurs dans la suspicion d'embolie pulmonaire et dans l'embolie pulmonaire confirmée. Journal des Maladies Vasculaires, 26, 23-30.

[4] Pio, M., Baragou, S., Afassinou, Y., Pessinaba, S., Atta, B., Ehlan, K., Goeh-akue, E. and Damorou, F. (2013) Actualité sur la maladie thromboembolique veineuse au CHU Sylvanus Olympio de Lome. Journal de la Recherche Scientifique de I Université de Lomé, 15, 93-100.

[5] Diall, I.B., Coulibaly, S., Minta, I., Ba, Ho., Diakite, M., Sidibe, N., et al. (2011) Etiologie, clinique et évolution de l'embolie pulmonaire à propos de 30 cas. Mali Médical, 26, 1-6.

[6] Niakara, A., Drabo, Y.J. and Cambered, Y. (2002) Cardiovascular Diseases and HIV Infection: Study of 79 Cases at the National Hospital of Ouagadougou (Burkina Faso). Bulletin de la Société de Pathologie Exotique, 95, 23-26.

[7] Maniboliot, M.S., Kanikomo, D., Ndiaye, M. and Sow, ML. (2013) La mort subite de l'adulte, particularités en Afrique, à propos de 476 cas. Pan African Medical Journal, 16, Article No. 125. https://doi.org/10.11604/pamj.2013.16.125.2490

[8] Olié, V., Chin, F., Lamarche-Vadel, A. and De Peretti, C. (2010) La maladie veineuse thromboembolique: Patients hospitalisés et mortalité en France en 2010. Bulletin Epidémiologique Hebdomadaire, No. 33-34, 417-424.

[9] Lambert, B. (2003) L'embolie pulmonaire en pratique clinique: À propos de 839 cas consécutifs en hôpital général: Étude STEP. Sciences du Vivant.

https://hal.univ-lorraine.fr/hal-01734190

[10] Bahloul, M., Chaari, A., Dammak, H., Abid, L., Salima, D., Ksibi, H., Samet, M., Kallel, H. and Bouaziz, M. (2014) L'embolie pulmonaire fibrino-cruorique: Fréquence, physiopathologie, tableau clinique et traitement. La tunisie médicale, 92, 435-447.

[11] Baragou, S., Pio, M., Afassinou, Y.M., Hountondji, A.F. and Dovi-Akue, G. (2013) Cardiovascular Risk Factors in Black African Obese Patients: A Multicentric Comparative Study in 1512 Patients in Lome (Togo). Obesity Weight Loss Therapy, 3, Article No. 184. https://doi.org/10.4172/2165-7904.1000184

[12] Van Hylckama Vlieg, A., Helmerhorst, F.M., Vandenbroucke, J.P., Doggen, C.J. and Rosendaal, F.R. (2009) The Venous Thrombotic Risk of Oral Contraceptives, Effects of Oestrogen Dose and Progestogen Type: Results of the Mega Case-Control Study. BMJ, 339, Article No. b2921. https://doi.org/10.1136/bmj.b2921

[13] N'djessan, J.J., Soya, E., Monney, E., Kouame, J., Takogue, R. and Konin, C. (2018) Evaluation de la mortalité précoce de l'embolie pulmonaire à l'Unité des Soins Intensifs de l'Institut de Cardiologie d'Abidjan. Cardiologie tropicale, No. 152, 44-55.

[14] Adoh, A., Kouame, A.N., Kouassi, Y.F., N’Dory, R. and Assambdi, M.O. (1992) Thromboses veineuses profondes des membres chez le sujet noir Africain. Médecine Tropicale, 52, 131-137.

[15] Pottier, P., Planchon, B., Pistorius, M.A. and Grolleau, J.Y. (2001) Facteurs de risque et incidence de la maladie thromboembolique veineuse en médecine interne: 
Une étude descriptive prospective sur 947 patients hospitalisés. Revue de Médecine Interne, 22, 348-359. https://doi.org/10.1016/S0248-8663(01)00347-2

[16] Mahe, I., Caulin, C. and Bergmann, J.F. (2005) L'âge, un facteur indépendant de risque de thrombose: Données épidémiologiques. La Presse Médicale, 34, 878-886. https://doi.org/10.1016/S0755-4982(05)84068-0

[17] Mongo Ngamami, S.F., Ellenga Mbolla, B.F., Kouala Landa, C.M., Makani Bassakouahou, J.K., Ikama, M.S., Bakekolo, R.P., et al. (2018) Aspects échocardiographies et scanographiques au cours de l'embolie pulmonaire aiguë dans le service de cardiologie du chu de Brazzaville (Congo). Annales de P université Marien N gouabi, 18, 51-57.

[18] Ghanima, W., Abdelnoor, M., Holmen, L.O., Nielssen, B.E., Ross, S. and Sandset, P.M. (2007) D-Dimer Level Is Associated with the Extent of Pulmonary Embolism. Thrombosis Research, 120, 281-288. https://doi.org/10.1016/j.thromres.2006.08.006

[19] Houenassi. M., Sacca-Vehounkpe, J., Tchabi, Y., Dossou-Yovo, R., Saizonou, F., Biaou, O., D’Almeida, M.M. and Agboton, H. (2013) Evaluation de la prise en charge de l'embolie pulmonaire dans un pays à faible niveau socio-économique: Cas du Bénin. Cardiologie Tropicale, 136, 1-5.

[20] Robert-Ebadi, H. and Righini, M. (2011) Diagnostic de l'embolie pulmonaire. Revue des Maladies Respiratoires, 28, 790-799. https://doi.org/10.1016/j.rmr.2010.10.039

[21] Pio, M., Goeh-akue, E., Baragou, S., Afassinou, Y., Sama, D.H., Mossi, K.E., Atta, B., Dandonougbo, K., Ehlan, E. and Damorou, F. (2014) Embolies pulmonaires: Signes cliniques et facteurs étiologiques au CHU Sylvanus Olympio de Lomé. Angéiologie, 66, 53-59. 